\title{
Vegetation changes in an abandoned montane grassland, compared to changes in a habitat with low-intensity sheep grazing - a case study in Styria, Austria
}

\author{
Andreas Bohner, Franz Starlinger \& Petr Koutecky
}

Keywords: abandonment, permanent plots, secondary succession, species turnover, management operations

\section{Abstract}

In protected areas maintaining existing phytodiversity is an important conservation target. In this study we analysed the effects of abandonment on plant species composition and species richness over a period of nine years in a montane grassland in the Long-term Ecosystem Research (LTER) region Eisenwurzen (Styria, Austria). Additional investigations concerned the number of Red Data List species, plant strategy types, Ellenberg indicator values, indicator values for mowing, grazing and trampling tolerance, temporal sequence of phenological phases and seven plant traits. We differentiated two topography-related habitat types: an initially species-rich sheep pasture on a steep, south-facing slope and a less species-rich meadow on a flat site immediately below, with a comparatively higher nutrient and water supply in the topsoil. Testing a possible management alternative, the effects of continued low-intensity sheep grazing on the slope were also analysed. In spring 2001, one permanent plot of $50 \mathrm{~m}^{2}$ was established in the centre of each habitat type and treatment. Our results show that the long-term effects of abandonment on grassland vegetation depend largely on local site conditions. Nutrient availability in the soil seems to be an especially important factor. On the abandoned flat site, floristic composition and physiognomy changed dramatically within four years; a high species turnover and a decline in phytodiversity could be observed. In contrast, we found only minor effects on the abandoned slope site even nine years after abandonment. If the maintenance of existing phytodiversity is a conservation target, suitable management operations have to be carried out at shorter intervals (at least every 3 years) in habitats with nutrient-rich soils than in nutrient-poor habitats (approx. 5 to 10 years). From a nature conservation point of view, low-intensity sheep grazing may be a suitable management alternative to mowing.
Profile

Long-term Ecosystem Research region

Eisenwurzen (Styria)

Mountain range

Alps

Country

Austria

\section{Introduction}

An important conservation target for protected areas is the maintenance of existing phytodiversity. In order to reach this target in permanent grassland, continuation of current management is necessary. However, due to financial constraints and labour shortage, a cessation of grassland management is taking place, especially on grassland with marginal agricultural value.

Cessation of grassland management causes alterations in plant species composition (Hard 1975; Schreiber \& Schiefer 1985). According to Persson (1984), vegetation changes are slower on dry soils compared to moist or fresh soils. In general, phytodiversity is decreasing as a result of abandonment (Willems 1985; Pykälä et al. 2005; Niedrist et al. 2009; Prévosto et al. 2011). Consequently, from a conservation point of view, there is a need for knowledge of strategies for the preservation of species-rich grassland under difficult socio-economic conditions, minimizing management costs. Thus, the main questions of our study were: - How long may abandoned grassland remain species-rich, depending on local site conditions?

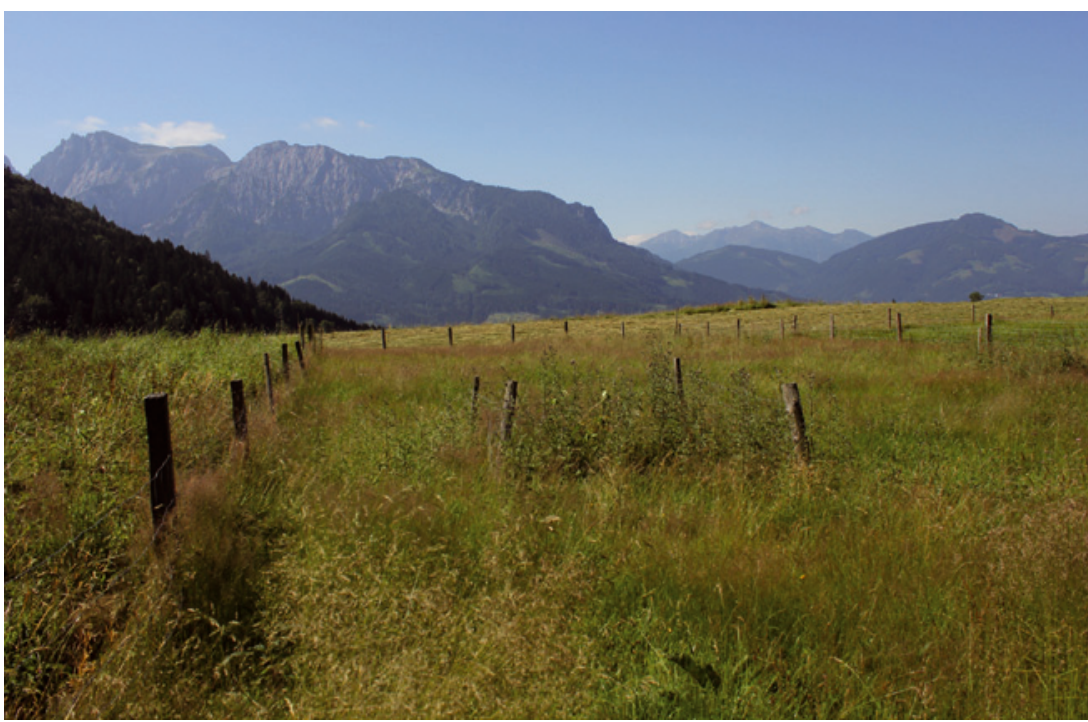

Figure 1 - The study site at Buchauer Sattel, near Admont, in the Long-term Ecosystem Research (LTER) region Eisenwurzen, Styria, Austria. (C) Andreas Bohner

Is low-intensity sheep grazing on steep slopes a suitable management alternative to mowing in conservation terms? 
To answer these questions, long-term floristic investigations on permanent plots are necessary. They must be based on a pedological site characterization. Although the emphasis of this paper has been on persistence of plant species richness after abandonment, the results of our case study can be used in setting priorities for conservation-oriented management operations in protected areas.

\section{Material and methods}

\section{Study site}

Our study was conducted at an altitude of 890

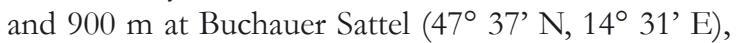
near Admont, in the Long-term Ecosystem Research (LTER) region Eisenwurzen, Styria, Austria. The study site is situated in the Northern Limestone Alps. The sub-oceanic climate is relatively cool and humid, with a mean annual air temperature of $+6.6{ }^{\circ} \mathrm{C}$ and a mean annual precipitation of $1400 \mathrm{~mm}$. Mean monthly air temperature varies from $-4.2{ }^{\circ} \mathrm{C}$ in January to $+16.3{ }^{\circ} \mathrm{C}$ in July (ZAMG 2002). Precipitation is distributed evenly throughout the year. The growing season is relatively short due to the long snow cover, lasting 110 days a year on average.

The effects of abandonment were studied in two different habitat types: a pasture on a steep $\left(30^{\circ}\right)$, south-facing slope and a meadow on a flat site immediately below. Before abandonment, the unfertilized pasture was grazed by sheep and the meadow, with two cuts per year, was regularly fertilized with farmyard manure. Initially, the flat site was covered with a Trisetetum flavescentis community (Polygono-Trisetion alliance) and the slope with a Festuco commutatae-Cynosuretum community (Cynosurion alliance). The abandoned areas were fenced against livestock, but browsing by wild animals (especially roe deer) still happened. On the steep slope, the effects of continued low-intensity sheep grazing on vegetation were also analysed. Therefore, adjacent to the abandoned area, approximately $1900 \mathrm{~m}^{2}$ were fenced. This area had been grazed by 15 mountain sheep three to four times per grazing season for a period of 7 days each time. The annual stocking rate was 0.4 livestock units per hectare. Grazing took place from May to October. To the north and to the east, the abandoned slope site is bordered by a mixed forest of spruce, silver fir and beech. The abandoned flat site is surrounded by grassland, but in a distance of $25 \mathrm{~m}$ a group of ash trees (Fraxinus excelsior) exists and the distance to the forest margin is $50 \mathrm{~m}$.

\section{Methods}

At the beginning of this study, in spring 2001, one permanent plot in the centre of each habitat type and treatment was established. All permanent plots had the same plot size of $50 \mathrm{~m}^{2}$. They were selected to be representative for each habitat type and treatment. From 2001 to 2009, vegetation surveys were carried out at each plot every two years, using the methods of Braun-Blanquet (1951) with a modified scale (Appendix 1). Only vascular plant species were recorded. Taxonomy and nomenclature follow that of Fischer et al. (2008).

The plant communities were analysed for:

- area of bare soil, vegetation cover, cover of species groups (grasses, herbs, legumes) and individual cover of all vascular plant species;

- alpha-diversity, evenness value and Red Data List species (Zimmermann et al. 1989);

- similarity indices: Beta-turnover (Shmida \& Wilson 1985), percentage similarity (Dahl \& Hadac 1949) and Soerensen index (Soerensen 1948);

- Ellenberg indicator values for light, soil moisture, soil reaction and nutrient availability (Ellenberg et al. 2001) as well as indicator values for mowing, grazing and trampling tolerance (Dierschke \& Briemle 2002), unweighted in each case;

- plant strategy types according to Grime (1979) and seven plant traits (Raunkiaer life form, type of reproduction, type of propagation and dispersal, leaf anatomy, leaf persistence, type of rosettes, type of pollination), in each case weighted by species cover; - temporal sequence of phenological phases throughout the growing season.

Plant strategy types and plant traits were extracted from the BIOLFLOR database (Klotz et al. 2002). For the phenological analysis we used the values according to Dierschke (1995).

In 2001, 2005 and 2007, composite soil samples were taken at each plot from the $0-10 \mathrm{~cm}$ soil layer (A horizon). Soil analyses (total organic carbon, total nitrogen, $\mathrm{pH}$, electrical conductivity, effective cation exchange capacity and exchangeable cations, lactate soluble phosphorus and potassium content) were carried out according to the ÖNORM methods (Austrian Standards Institute).

\section{Results}

Soil

At each plot, the soil represents a deep brown loam (Chromic Cambisol) developed over a calcareous moraine. The texture of the carbonate-free topsoil (A horizon) is loamy silt. The crumb and angular blocky structure indicates no soil compaction. Even in the abandoned plots, only small quantities of herbaceous litter at the soil surface can be observed throughout the year. The soil water regime is periodically moist in the topsoil. The stagnic properties are caused by the loamy silt texture, leading to an inhibited infiltration of water from rainfall or snowmelt. On the flat site, wet periods are longer and dry periods are considerably shorter than on the slope. In 2001, the topsoils were in the cation exchange buffer range ( Table 1). Base saturation ranged from 75 to $96 \%$. On the flat site, the $\mathrm{C}_{\text {org }}$ to $\mathrm{N}_{\text {tot }}$ ratio was narrower than on the slope, whereas electrical conductivity and lactate soluble phosphorus content were higher. So far, aban- 
Table 1 - Selected soil chemical properties at the beginning of this study (A horizon, 0-10 cm soil depth). Electrical conductivity (EC); effective cation exchange capacity $\left(\mathrm{CEC}_{\text {eff }}\right)\left(\mathrm{BaCl}_{2}\right.$-extract); base saturation (BS) ( $\mathrm{BaCl}_{2}$-extract); lactate soluble phosphorus and potassium content $\left(P_{C A L}, K_{C A L}\right)$.

\begin{tabular}{|c|c|c|c|c|c|c|c|c|c|}
\hline \multirow[t]{2}{*}{ Site } & $\mathrm{C}_{\text {org }}$ & $\mathbf{N}_{\text {tot }}$ & \multirow[t]{2}{*}{$\mathrm{C}_{\text {org }}: \mathrm{N}_{\text {tot }}$} & \multirow{2}{*}{\begin{tabular}{|c|}
$\mathrm{pH}$ \\
$\mathrm{CaCl}_{2}$ \\
\end{tabular}} & \multirow{2}{*}{\begin{tabular}{|c|}
$\mathrm{EC}$ \\
$\mu \mathrm{S} \mathrm{cm}^{-1}$
\end{tabular}} & \multirow{2}{*}{$\begin{array}{c}\mathrm{CEC}_{\text {eff }} \\
\mathrm{cmol}_{\mathrm{c}} \mathrm{kg}^{-1}\end{array}$} & \multirow{2}{*}{$\begin{array}{l}\text { BS } \\
\% \\
\end{array}$} & \multirow{2}{*}{\multicolumn{2}{|c|}{$\mathbf{m g ~ k g}{ }^{-1}$}} \\
\hline & $\%$ & & & & & & & & \\
\hline flat a & 4.52 & 0.41 & 11.02 & 4.78 & 57 & 11.6 & 93 & 15 & 48 \\
\hline slope a & 4.42 & 0.38 & 11.63 & 4.34 & 36 & 9.0 & 75 & 8 & 50 \\
\hline slope $\mathrm{g}$ & 3.97 & 0.33 & 12.03 & 4.85 & 37 & 12.1 & 96 & 7 & 37 \\
\hline
\end{tabular}

Abandoned flat site (flat a); abandoned slope site (slope a); grazed slope site (slope g).

Table 2 - Vegetation changes during the period 2001-2009.

\begin{tabular}{|l|r|r|r|}
\hline Vegetation change & flat a & slope a & slope g \\
\hline a-diversity 2001 & 48 & 73 & 74 \\
\hline a-diversity 2009 & 22 & 70 & 74 \\
\hline change in $\boldsymbol{\alpha}$-diversity & -26 & -3 & 0 \\
\hline number of new species & 2 & 8 & 5 \\
\hline number of extinct species & 28 & 11 & 5 \\
\hline evenness value 2001 & 84 & 85 & 86 \\
\hline evenness value 2009 & 47 & 79 & 83 \\
\hline beta-turnover 2001-2009 & 0,41 & 0,13 & 0,07 \\
\hline percentage similarity 2001-2009 & 27 & 58 & 68 \\
\hline Soerensen index 2001-2009 & 57 & 87 & 93 \\
\hline
\end{tabular}

Abandoned flat site (flat a); abandoned slope site (slope a); grazed slope site (slope g).

Table 3 - Changes in the unweighted mean indicator values during the period 2001-2009.

\begin{tabular}{|l|r|r|r|r|r|r|}
\hline \multirow{2}{*}{$\begin{array}{l}\text { Indicator } \\
\text { value }\end{array}$} & \multicolumn{2}{|c|}{ flat a } & \multicolumn{2}{c|}{ slope a } & \multicolumn{2}{c|}{ slope g } \\
\cline { 2 - 7 } & $\mathbf{2 0 0 1}$ & $\mathbf{2 0 0 9}$ & $\mathbf{2 0 0 1}$ & $\mathbf{2 0 0 9}$ & $\mathbf{2 0 0 1}$ & $\mathbf{2 0 0 9}$ \\
\hline light & 7 & 6 & 7 & 6 & 7 & 7 \\
\hline soil moisture & 6 & 6 & 5 & 5 & 5 & 5 \\
\hline soil reaction & 6 & 5 & 6 & 5 & 6 & 6 \\
\hline $\begin{array}{l}\text { nutrient avail- } \\
\text { ability }\end{array}$ & 6 & 6 & 4 & 4 & 4 & 4 \\
\hline mowing & 7 & 6 & 5 & 5 & 5 & 5 \\
\hline grazing & 5 & 4 & 5 & 5 & 5 & 5 \\
\hline trampling & 5 & 4 & 5 & 4 & 4 & 5 \\
\hline
\end{tabular}

Abandoned flat site (flat a); abandoned slope site (slope a); grazed slope site (slope g).

donment has had no significant effect on the investigated soil properties. Therefore, a documentation and interpretation of the data is not useful at the moment.

\section{Vegetation}

The investigated habitat types differed considerably in their response to abandonment (Appendix 2, 3). On the flat site, we observed relatively large vegetation changes during the first 4 years after abandonment. From that time onwards, changes in species composition, species cover and species richness were smaller, indicating a period of stagnation. During the investigation period, herbs increased in cover from $40 \%$ in 2001 to $97 \%$ in 2009 at the expense of both grasses and legumes. The similarity indices show a comparatively high species turnover (Table 2). The cover of Chaerophyllum hirsutum and Ficaria verna increased considerably. During the first 4 years of investigation, C. hirsutum became dominant, resulting in a decline of the evenness value (Table 2). After abandonment, the area of bare soil beneath the dense canopy dominated by leaves of C. hirsutum increased from 8\% in 2001 to $50 \%$ in 2009 . Alpha-diversity (total number of vascular plant species within a plot size of $50 \mathrm{~m}^{2}$ ) decreased from initially 48 plant species in 2001 to 22 in 2009. When we compare species composition in these two years, only 2 new species (Galeopsis tetrabit, Holcus mollis) appeared, whereas 28 disappeared. Species with decreasing cover and species which disappeared were mainly low-growing, light-demanding grassland species and tall grasses, resulting in a change of the vegetation type. The initial Trisetetum flavescentis community has been replaced by a $C$. birsutum stage. To date, we have found no shrub or tree species, neither as seedlings nor as saplings.

In contrast, on the abandoned slope site, vegetation changes were small, even 9 years after abandonment. During the investigation period, herbs increased in cover from $50 \%$ in 2001 to $55 \%$ in 2009 at the expense of grasses. Alpha-diversity decreased from initially 73 plant species in 2001 to 70 in 2009. When we compare species composition in these two years, 8 new species appeared, whereas 11 disappeared. Of the species initially present, particularly Clinopodium vulgare, Molinia caerulea and Prunus spinosa increased in cover. So far, abundance and cover of woody plants (tree seedlings and saplings, shrubs) are relatively low within the permanent plot. However, the clonal spread of P. spinosa has led to higher structural diversity. By now, this shrub has achieved a maximum plant height of up to $1.5 \mathrm{~m}$. The current successional stage is characterized by high species richness and evenness, indicating the absence of dominant species.

In the sheep pasture, until now, only minor damages due to trampling and selective defoliation could be observed. The vegetation cover on the permanent plot was on average $80 \%$ but varied considerably within and between the years. During the investigation period, vegetation changes were small (Appendix 4). Primarily Cynosurus cristatus and Prunella vulgaris increased in cover, whereas Hypericum maculatum, Polygala vulgaris ssp.vulgaris and Pteridium aquilinum decreased. The similarity indices show a low species turnover. The initially high phytodiversity did not change. Both in 2001 and 2009, we recorded 74 plant species within $50 \mathrm{~m}^{2}$. The relatively high evenness indicates that no species has become dominant. 
Table 4 - Changes in the cover-weighted Raunkiaer life-form spectra during the period 2001-2009.

\begin{tabular}{|l|r|r|r|r|r|r|}
\hline \multirow{2}{*}{$\begin{array}{l}\text { Raunkiaer life- } \\
\text { form spectra }\end{array}$} & \multicolumn{2}{|c|}{ flat a } & \multicolumn{2}{|c|}{ slope a } & \multicolumn{2}{c|}{ slope g } \\
\cline { 2 - 7 } & $\mathbf{2 0 0 1}$ & $\mathbf{2 0 0 9}$ & $\mathbf{2 0 0 1}$ & $\mathbf{2 0 0 9}$ & $\mathbf{2 0 0 1}$ & $\mathbf{2 0 0 9}$ \\
\hline therophytes & 0.4 & 3.1 & 0.6 & 0.3 & 0.2 & 0.4 \\
\hline hemicryptophytes & 93.9 & 85.3 & 82.4 & 78.3 & 84.0 & 83.1 \\
\hline geophytes & 0.5 & 10.6 & 10.5 & 10.3 & 9.0 & 5.5 \\
\hline chamaephytes & 5.1 & 1.0 & 2.2 & 1.5 & 3.3 & 6.1 \\
\hline phanerophytes & 0.0 & 0.0 & 2.1 & 8.3 & 0.3 & 1.2 \\
\hline
\end{tabular}

Abandoned flat site (flat a); abandoned slope site (slope a); grazed slope site (slope g).

Table 5 - Changes in the cover-weighted spectra of strategy types during the period 2001-2009.

\begin{tabular}{|l|r|r|r|r|r|r|r|}
\hline \multirow{2}{*}{ Strategy types } & \multicolumn{2}{|c|}{ flat a } & \multicolumn{2}{c|}{ slope a } & \multicolumn{2}{c|}{ slope g } \\
\cline { 2 - 7 } & $\mathbf{2 0 0 1}$ & $\mathbf{2 0 0 9}$ & $\mathbf{2 0 0 1}$ & $\mathbf{2 0 0 9}$ & $\mathbf{2 0 0 1}$ & $\mathbf{2 0 0 9}$ \\
\hline competitors & 47.5 & 71.3 & 41.3 & 56.6 & 32.4 & 35.5 \\
\hline $\begin{array}{l}\text { competitive ruder- } \\
\text { als }\end{array}$ & 0.3 & 3.1 & 0.3 & 0.0 & 0.6 & 0.3 \\
\hline $\begin{array}{l}\text { stress-tolerant } \\
\text { competitors }\end{array}$ & 1.2 & 0.4 & 11.6 & 21.5 & 13.0 & 6.7 \\
\hline CSR strategists & 50.1 & 25.2 & 46.2 & 21.6 & 53.7 & 57.2 \\
\hline ruderals & 0.9 & 0.0 & 0.3 & 0.0 & 0.2 & 0.3 \\
\hline stress-tolerators & 0.0 & 0.0 & 0.0 & 0.0 & 0.0 & 0.0 \\
\hline $\begin{array}{l}\text { stress-tolerant } \\
\text { ruderals }\end{array}$ & 0.0 & 0.0 & 0.3 & 0.0 & 0.0 & 0.0 \\
\hline
\end{tabular}

Abandoned flat site (flat a); abandoned slope site (slope a); grazed slope site (slope g).

We found no rare or highly endangered plant species in the plots investigated. After abandonment, mainly common and widely distributed species appeared. In the abandoned areas, invasive neophytes have so far been absent.

During the investigation period, mean Ellenberg indicator values for light and soil reaction decreased on the abandoned sites (Table 3). The mean indicator value for trampling tolerance decreased in the abandoned plots and increased in the grazed plot. On the abandoned flat site we also observed a decrease in the indicator values for mowing and grazing tolerance.

In the plant stands investigated, hemicryptophytes are prevalent (Table 4). Meanwhile, in the abandoned plots, geophytes achieve the second-highest cover. On the abandoned flat site, a considerable increase in the cover of geophytes and, to a much lesser extent, of therophytes at the expense of both hemicryptophytes and chamaephytes could be observed. On the abandoned slope site, however, a spread of shrubs led to an increase in the cover of phanerophytes. On the grazed slope site, the cover of chamaephytes increased at the expense of geophytes.

The cover-weighted life strategy analysis reveals that the plant stands investigated are dominated by competitors and CSR strategists (Table 5). In the plant communities on the slope, stress-tolerant competitors also achieve a relatively high cover. In the abandoned plots, the cover of competitors increased at the expense of CSR strategists. On the abandoned slope site, stress-tolerant competitors also showed a significant increase in cover, in contrast to the grazed slope site characterized by a decreasing importance of this life strategy type.

Analysis of plant traits weighted by cover shows both similar and contrasting plant responses to abandonment between the different sites, depending on the respective plant trait (Table 6 ). In the investigated plant stands, species reproducing themselves by seed and vegetatively are prevalent. In the abandoned plots, their cover increased, mainly at the expense of the reproduction group only by seed. On the abandoned flat site, species reproducing themselves mostly by seed, rarely vegetatively also showed a distinct decrease. Vegetative propagation by lateral shoots (runners) is an important type of reproduction in all plots. On the abandoned flat site, propagation by rhizomes decreased markedly. In the plant communities on the slope, mesomorphic leaf anatomy is clearly dominant, whereas hygromorphic leaf anatomy is of minor importance. Plant species with scleromorphic leaves also achieve a remarkable cover. On the abandoned flat site, hygromorphic leaf anatomy increased significantly and dominates now. After abandonment, the proportion of species with summer-green leaves increased, whereas the proportion of species with persistent green leaves decreased. On the abandoned flat site, plants with spring-green leaves also increased. In all plots, hemirosette plants achieve the highest cover. On the abandoned flat site, rosette plants decreased considerably, whereas on the abandoned slope site an opposite effect could be observed. Species characterized by leaves that are evenly distributed along the stem (erosulate plants) decreased after abandonment and have disappeared completely on the flat site. In all plots, insect-pollinated plants achieve the highest cover. Their proportion increased after abandonment, whereas wind-pollinated plants decreased, especially on the flat site.

At present, the plant communities on the abandoned plots differ greatly in physiognomy. In the species-rich plant stand on the slope, herbs achieve a relatively high cover of about $55 \%$. Therefore, in the current stage of succession, the phytocoenosis is characterized by a rather evenly distributed and broad spectrum of phenophases with a high number of flowers from the beginning of early spring to mid-summer (Table 7). Consequently, this plant stand, colourful when in bloom, has a high aesthetic value. There is also a great food supply for flower-visiting insects, especially at mid-summer. In contrast, abandonment has led to a marked shift in the seasonal aspects of the vegetation on the flat site. At present, the species-poor phytocoenosis is dominated by $C$. hirsutum and F. verna, each forming a striking aspect at the beginning of early spring and end of spring, respectively. So, the phenophases are less evenly distributed throughout the vegetation period, resulting in a lower aesthetic value for most of the year. 


\section{Discussion}

Results from the soil analyses $\left(\mathrm{C}_{\text {org }}\right.$ to $\mathrm{N}_{\text {tot }}$ ratio, electrical conductivity, lactate soluble phosphorus content) indicate better nutrient supply on the flat site than on the slope. The higher phosphorus content probably is a residual effect of farmyard manure applied before abandonment. On the slope, nutrient deficiency seems to be the main limiting factor for plant growth. Periodical or occasional drought should be of minor importance due to the cool and humid climate, in combination with a deep, fine-textured soil, resulting in a high water-holding capacity. This is corroborated by the higher mean Ellenberg indicator value for nutrient availability on the flat site compared to the slope, whereas the mean Ellenberg value for soil moisture is only slightly lower on the slope. Furthermore, the occurrence of numerous stress-tolerant competitors on the slope indicates moderate nutrient stress.

Cessation of grassland management favours plant species that are less tolerant to mowing, grazing and particularly trampling, whereas shade-intolerant grassland species are sensitive to abandonment. In an early successional stage, mainly geophytes or phanerophytes benefit from a lack of disturbance, depending on the habitat type. Results from Briemle \& Schreiber (1994) confirm this phenomenon. Competitors are frequently found in habitats where stress and disturbance are minimal (Wilson \& Keddy 1986). Thus, the abundance of competitors increases during secondary succession. Abandonment favours species reproducing themselves by seed and vegetatively, species with summer green leaves and insect-pollinated species at the expense of species reproducing themselves only by seed, species with persistent green leaves and wind-pollinated species. Especially on the abandoned flat site, reproduction by seeds is a very unfavourable strategy due to a dense leaf canopy. However, the newly recorded therophyte $G$. tetrabit at this site acts as an early invader. This species is absent from regularly managed grassland. The decreasing importance of wind-pollinated species and species with persistent green leaves after abandonment can be explained by the reduction of grasses. In general, rosette plants have a high requirement for light and they benefit from frequent disturbances (Kleyer 1999). Thus, abandonment also caused a marked decrease in the abundance of rosette plants on the flat site.

The observed smaller and delayed vegetation changes on the abandoned slope site compared to the abandoned flat site are likely the result of different nutrient availability in the soil. In addition, the small differences in soil water regime may have an influence, primarily due to soil moisture affecting nutrient availability. Because of the less fertile soil on the slope, short- to medium-sized, fine-leaved grasses with mainly vertically orientated leaves achieve a comparatively higher cover, resulting in better light conditions at the soil surface. Therefore, more light-demanding grassland species of
Table 6 - Changes in the cover-weighted plant traits during the period $2001-2009$.

\begin{tabular}{|c|c|c|c|c|c|c|}
\hline \multirow[t]{2}{*}{ Plant trait } & \multicolumn{2}{|c|}{ flat a } & \multicolumn{2}{|c|}{ slope a } & \multicolumn{2}{|c|}{ slope $\mathrm{g}$} \\
\hline & 2001 & 2009 & 2001 & 2009 & 2001 & 2009 \\
\hline \multicolumn{7}{|l|}{ Type of reproduction } \\
\hline only by seed & 7.9 & 3.1 & 12.9 & 4.2 & 19.3 & 20.7 \\
\hline mostly by seed, rarely vegetatively & 19.3 & 4.2 & 6.2 & 7.9 & 12.4 & 14.1 \\
\hline by seed and vegetatively & 66.9 & 70.5 & 74.8 & 85.3 & 63.8 & 63.6 \\
\hline mostly vegetatively, rarely by seed & 5.5 & 2.1 & 6.1 & 2.6 & 4.6 & 1.6 \\
\hline only vegetatively & 0.0 & 0.0 & 0.0 & 0.0 & 0.0 & 0.0 \\
\hline \multicolumn{7}{|l|}{ Type of propagation and dispersal } \\
\hline runner & 65.4 & 68.4 & 42.8 & 41.1 & 34.5 & 37.7 \\
\hline rhizome & 23.5 & 5.1 & 31.6 & 36.9 & 38.2 & 31.1 \\
\hline rhizome-like pleiocorm & 3.1 & 0.8 & 1.9 & 0.3 & 6.9 & 7.4 \\
\hline root-shoot & 0.0 & 0.0 & 3.3 & 7.9 & 1.7 & 2.1 \\
\hline \multicolumn{7}{|l|}{ Leaf anatomy } \\
\hline scleromorphic & 1.3 & 0.0 & 23.2 & 23.7 & 22.0 & 20.0 \\
\hline mesomorphic & 59.8 & 12.2 & 68.9 & 65.2 & 68.4 & 72.5 \\
\hline hygromorphic & 29.9 & 86.5 & 5.2 & 6.0 & 5.1 & 3.1 \\
\hline \multicolumn{7}{|l|}{ Leaf persistence } \\
\hline spring green & 0.3 & 20.1 & 0.3 & 0.3 & 0.5 & 0.3 \\
\hline summer green & 41.5 & 74.0 & 56.3 & 69.4 & 54.5 & 47.1 \\
\hline overwintering green & 0.9 & 0.0 & 0.3 & 0.0 & 0.0 & 0.3 \\
\hline persistent green & 57.3 & 5.8 & 42.5 & 29.1 & 44.8 & 52.1 \\
\hline \multicolumn{7}{|l|}{ Type of rosettes } \\
\hline rosette plant & 22.9 & 7.5 & 27.8 & 47.1 & 28.7 & 29.8 \\
\hline hemirosette plant & 73.2 & 92.5 & 65.9 & 47.9 & 57.0 & 50.7 \\
\hline erosulate plant & 3.9 & 0.0 & 6.4 & 5.0 & 14.3 & 19.5 \\
\hline \multicolumn{7}{|l|}{ Type of pollination } \\
\hline wind & 25.8 & 4.4 & 37.3 & 30.1 & 31.8 & 31.9 \\
\hline insects & 52.1 & 90.6 & 42.3 & 45.0 & 46.0 & 45.1 \\
\hline selfing & 15.4 & 5.0 & 13.6 & 17.1 & 16.2 & 20.1 \\
\hline
\end{tabular}

Abandoned flat site (flat a); abandoned slope site (slope a); grazed slope site (slope g).

Table 7 - Changes in the cover-weighted spectra of phenophases during the period 2001-2009. Earliest spring (1), beginning of early spring (2), end of early spring (3), beginning of spring (4), end of spring (5), beginning of early summer (6), end of early summer (7), mid-summer (8), early autumn (9), no classification (10).

\begin{tabular}{|l|r|r|r|r|r|r|r|r|r|r|}
\hline \multirow{2}{*}{ Site } & \multicolumn{10}{|c|}{ phenophases (\%) } \\
\cline { 2 - 12 } & $\mathbf{1}$ & $\mathbf{2}$ & $\mathbf{3}$ & $\mathbf{4}$ & $\mathbf{5}$ & $\mathbf{6}$ & $\mathbf{7}$ & $\mathbf{8}$ & $\mathbf{9}$ & $\mathbf{1 0}$ \\
\hline flat a 2001 & 0 & 1 & 5 & 15 & 32 & 20 & 18 & 2 & 0 & 7 \\
\hline flat a 2009 & 0 & 20 & 1 & 3 & 65 & 3 & 2 & 6 & 0 & 0 \\
\hline slope a 2001 & 0 & 1 & 3 & 14 & 11 & 28 & 8 & 30 & 0 & 5 \\
\hline slope a 2009 & 0 & 1 & 9 & 8 & 5 & 22 & 15 & 33 & 0 & 7 \\
\hline slope g 2001 & 0 & 1 & 4 & 26 & 10 & 22 & 11 & 22 & 0 & 4 \\
\hline slope g 2009 & 0 & 1 & 5 & 15 & 5 & 29 & 17 & 26 & 0 & 2 \\
\hline
\end{tabular}

Abandoned flat site (flat a); abandoned slope site (slope a); grazed slope site (slope g).

short stature could survive after abandonment. The newcomers mainly included species characteristic of forest margins (e.g. Agrimonia eupatoria, Cuscuta epithymum, Hieracium laevigatum).

In contrast, on the abandoned flat site, many low-growing and shade-intolerant grassland species were suppressed primarily by the dominant species C. birsutum. Due to its broad and mainly horizontally orientated leaves, concentrated at $13-17 \mathrm{~cm}$ above 
soil surface, $C$. hirsutum overshadows all other smaller species. Therefore, only a few shade-tolerant species and gap exploiters were able to co-exist on the abandoned flat site. The latter may benefit from temporal gaps in the leaf canopy. The vernal geophyte F. verna and the late-developing therophyte $G$. tetrabit, for example, minimize light competition with the summergreen Chaerophyllum plants by growing and flowering early or late in the growing season.

The results of our study suggest that on nutrientrich grassland soils abandonment in an early successional stage favours the spread of a few highly competitive, tall herbs, resulting in rapid vegetation change and a strong decrease in species richness. Within less than 5 years this is followed by a period of stagnation, characterized by a species-poor, herb-dominated stage. This finding is consistent with Shugart \& Hett (1973), who observed that during secondary succession species loss decelerates with time.

Up to now, no woody species were recorded on the abandoned flat site. This can neither be explained by a lack of seed input from the surrounding vegetation nor by a closed sward or large amounts of litter and necromass. Litter from $C$. birsutum seems to be easy decomposable and therefore not inhibitory to seedling establishment. Competitive herbs, however, possess the ability to produce a dense leaf canopy (AlMufti et al. 1977). Despite plenty of bare soil beneath the Chaerophyllum canopy, germination of seeds and seedling development of woody plants are prevented through shading. This is consistent with results from Smit \& Olff (1998), who observed that on nutrientrich soils the colonisation rate of woody species is slower than on nutrient-poor soils. It can also be considered that $C$. hirsutum may act as a succession retardant by allelopathy. Kaligaric et al. (2011) report that some tall umbellifers tend to form monodominant plant stands after abandonment due to their allelopathic potential.

In August 2011, at the peak of growing season, we measured the above-ground plant biomass in the abandoned plots. Surprisingly, dry matter was lower on the flat site than on the slope $\left(39 \mathrm{dt} \mathrm{ha}^{-1}\right.$ versus $\left.47 \mathrm{dt} \mathrm{ha}^{-1}\right)$, despite better nutrient supply. This finding suggests that, beside the above-ground plant biomass production, the growth form of the dominant species and consequently height and density of the vegetation canopy have an important influence on secondary succession. Willems (1985) also emphasizes the importance of the growth form for vegetation development.

At the beginning of succession, shrubs such as $P$. spinosa were already present in the plant community on the slope. Meanwhile, due to abandonment, $P$. spinosa has achieved a high cover, especially on the lower part of the slope, and is invading from there into the permanent plot. The establishment of a P. spinosa scrub on the lower part of the slope indicates that the next successional stage on the permanent plot may also be a $P$. spinosa stage. This finding suggests that species composition at the time of abandonment de- termines vegetation development after abandonment considerably (Initial Floristic Composition according to Egler 1954). Abandoned grassland may occasionally remain shrub- or treeless for decades if saplings were not present when management ceased (Hard 1975; Persson 1984).

In sum, even in an early successional stage, our findings more or less confirm the intermediate disturbance hypothesis (Connell 1978) which assumes that a lack of disturbance should lead to a decrease in phytodiversity. However, our results indicate that speed and magnitude of species loss largely depend on abiotic site conditions and on time elapsed since abandonment. The initial plant species composition and the growth form of the dominant species also play a key role.

Up to now, we could not observe any significant vegetation change in the species-rich sheep pasture. Therefore it seems reasonable to assume that from a nature conservation point of view low-intensity sheep grazing is a suitable management practice on the steep slope and is fully compatible with conservation targets.

\section{Conclusion}

The results of our study suggest that nutrient availability in the soil is an important factor for vegetation changes in an abandoned montane grassland. Speed and magnitude of diversity loss are higher on nutrientrich soils than on nutrient-poor soils. Thus, if plant species richness is to be maintained, suitable management operations have to be carried out at shorter intervals (at least every 3 years) in habitats with nutrientrich soils compared to nutrient-poor habitats (approx. 5 to 10 years). From a nature conservation point of view, low-intensity sheep grazing may be a suitable alternative management regime to mowing.

\section{Acknowledgements}

For the determination of critical plant species we thank Günter Gottschlich (Hieracium) and Franz Grims (Alchemilla). Furthermore, we thank two anonymous reviewers for valuable comments on the manuscript.

\section{References}

Al-Mufti, M.M., C.L. Sydes, S.B. Furness, J.P. Grime \& S.R. Band 1977. A quantitative analysis of shoot phenology and dominance in herbaceous vegetation. Journal of Ecology 65: 759-791.

Braun-Blanquet, J. 1951. Pflanzensoziolgie. Grundzüge der Vegetationskunde. 2. Auflage. Wien.

Briemle, G. \& K.-F. Schreiber 1994. Zur Frage der Beeinflussung pflanzlicher Lebens- und Wuchsformen durch unterschiedliche Landschaftspflegemaßnahmen. Tuexenia 14: 229-244.

Connell, J.H. 1978. Diversity in tropical rain forests and coral reefs. Science 199: 1302-1310. 
Dahl, E. \& E. Hadac 1949. Homogenity of plant communities. Studies in Botany of Czechoslovakia 10: 159-176.

Dierschke, H. 1995. Phänologische und symphänologische Artengruppen von Blütenpflanzen Mitteleuropas. Tuexenia 15: 523-560.

Dierschke, H. \& G. Briemle 2002. Kulturgrasland. Stuttgart.

Egler, F.E. 1954. Vegetation science concepts. I. Initial floristic composition, a factor in old-field vegetation development. Vegetatio 4: 412-417.

Ellenberg, H., H.E. Weber, R. Düll, V. Wirth \& W. Werner 2001. Zeigerwerte von Pflanzen in Mitteleuropa. Scripta Geobotanica 18. 3. Auflage. Göttingen.

Fischer, M.A., K. Oswald \& W. Adler 2008. Exkursionsflora für Österreich, Liechtenstein, Südtirol. 3. Auflage. Biologiezentrum der Oberösterreichischen Landesmuseen

Grime, J.P. 1979. Plant strategies and vegetation processes. Chichester.

Hard, G. 1975. Vegetationsdynamik und Verwaldungsprozesse auf den Brachflächen Mitteleuropas. Die Erde 106: 243-276.

Kaligaric, M., M.H. Meister, S. Skornik, N. Sajna, B. Kramberger \& H.R. Bolhar-Nordenkampf 2011. Grassland succession is mediated by umbelliferous colonizers showing allelopathic potential. Plant Biosystems 145: 688-698.

Kleyer, M. 1999. Distribution of plant functional types along gradients of disturbance intensity and resource supply in an agricultural land scape. Journal of Vegetation Science 10: 697-708.

Klotz, S., I. Kühn \& W. Durka 2002. BIOLFLOR - Eine Datenbank mit biologisch-ökologischen Merkmalen zur Flora von Deutschland. Schriftenreihe für Vegetationskunde 38.

Niedrist, G., E. Tasser, C. Lüth, J. Dalla Via \& U. Tappeiner 2009. Plant diversity declines with recent land use changes in European Alps. Plant Ecology 202: 195-210.

Persson, S. 1984. Vegetation development after the exclusion of grazing cattle in a meadow area in the south of Sweden. Vegetatio 55: 65-92.

Prévosto, B., L. Kuiters, M. Bernhardt-Römermann, M. Dölle, W. Schmidt, M. Hoffmann, J. van Uytvanck, A. Bohner, D. Kreiner, J. Stadler, S. Klotz \& R. Brandl 2011. Impacts of Land Abandonment on Vegetation: Successional Pathways in European Habitats. Folia Geobotanica 46: 303-325.

Pykälä, J., M. Luoto, R.K. Heikkinen \& T. Kontula 2005. Plant species richness and persistence of rare plants in abandoned semi-natural grasslands in northern Europe. Basic and Applied Ecology 6: 25-33.

Schreiber, K.-F. \& J. Schiefer 1985. Vegetations- und Stoffdynamik in Grünlandbrachen - 10 Jahre Bracheversuche in Baden-Württemberg. In: Schreiber, K.-F. (Hrsg.), Sukzession auf Grünlandbrachen: 111-153.

Shmida, A. \& M.V. Wilson 1985. Biological determinants of species diversity. Journal of Biogeography 12:1-20.
Shugart, H.H. \& J.M. Hett 1973. Succession: similarities of species turnover rates. Science 180: 1379_ 1381.

Smit, R. \& H. Olff 1998. Woody species colonisation in relation to habitat productivity. Plant Ecology 139: 203-209.

Soerensen, T.A. 1948. A method of establishing groups of equal amplitude in plant sociology based on similarity of species content, and its application to analyses of the vegetation on Danish commons. Biologiske Skrifter Danske Videnskabernes Selskab 5: 1-34.

Willems, J.H. 1985. Growth form spectra and species diversity in permanent grassland plots with different management. In: Schreiber, K.-F. (Hrsg.), Sukzession auf Grünlandbrachen: 35-43.

Wilson, S.D. \& P.A. Keddy 1986. Species competitive ability and position along a natural stress/disturbance gradient. Ecology 67: 1236-1242.

ZAMG (Central Institute for Meteorology and Geodynamics) 2002. Klimadaten von Österreich 19712000. Available at: http://www.zamg.ac.at/fix/klima/ oe71-00/klima2000/klimadaten_oesterreich_1971_ frame1.htm.

Zimmermann, A., G. Kniely, H. Melzer, W. Maurer \& R. Höllriegl 1989. Atlas gefährdeter Farn- und Blütenpflanzen der Steiermark. Joanneum-Verein.

\section{Authors}

\section{Dr. Andreas Bohner}

Head of the Department of Environmental Ecology at the Agricultural Research and Education Centre Raumberg-Gumpenstein; lecturer at the University of Natural Resources and Applied Life Sciences, Vienna.

Field of research: grassland ecology, soil-plant-relationships, indicator values of grassland species, biodiversity, nature conservation.

Agricultural Research and Education Centre Raumberg-Gumpenstein, Raumberg 38, 8952 Irdning, Austria; email: andreas.bohner@raumberg-gumpenstein.at

\section{Dr. Franz Starlinger}

Field of research: vegetation ecology of forest ecosystems, vegetation monitoring, phytosociology, forest site classification. Federal Research and Training Centre for Forests, Natural Hazards and Landscape, Department of Forest Ecology and Soils, Unit of Site and Vegetation Research, Seckendorff-Gudent-Weg 8; 1131 Vienna, Austria; email: franz.starlinger@bfw.gv.at

\section{PhD Petr Koutecky}

Assistant Professor at the University of South Bohemia, Head of the Laboratory of Plant Molecular Biology. Field of research: plant systematics and taxonomy, microevolutionary processes, flow cytometry, molecular methods, statistical analysis

University of South Bohemia, Faculty of Science, Department of Botany, Branisovská 31, 37005 Ceské Budejovice, Czechoslovakia; email: kouta@prf.jcu.cz 
Appendix 1 - Scale of the percentage cover values according to a modified Braun-Blanquet method.

\begin{tabular}{|l|r|}
\hline Braun-Blanquet method & \% cover \\
\hline$r$ & 0.2 \\
\hline+ & $0.3-0.9$ \\
\hline $1 a$ & $1-1.9$ \\
\hline 1 & $2-3.9$ \\
\hline $1 b$ & $4-5$ \\
\hline $2 a$ & $6-11$ \\
\hline 2 & $12-19$ \\
\hline $2 b$ & $20-25$ \\
\hline $3 a$ & $26-32$ \\
\hline 3 & $33-44$ \\
\hline $3 b$ & $45-50$ \\
\hline $4 a$ & $51-56$ \\
\hline 4 & $57-68$ \\
\hline $4 b$ & $69-75$ \\
\hline $5 a$ & $76-81$ \\
\hline 5 & $82-94$ \\
\hline $5 b$ & $95-100$ \\
\hline
\end{tabular}

Appendix 2 - Changes in the vascular plant species composition on the abandoned flat site during the period $2001-2009$

\section{Species}

Achillea millefolium agg.

Aegopodium podagraria

Agrostis capillaris

Agrostis stolonifera

Ajuga reptans

Alchemilla monticola

Alopecurus pratensis

Anthoxanthum odoratum

Astrantia major var. major

Bellis perennis

Calycocorsus stipitatus

Cerastium holosteoides

Chaerophyllum hirsutum

Cirsium oleraceum

Crepis aurea

Crocus albiflorus

Dactylis glomerata ssp.glomerata

Elymus repens

Festuca pratensis

Festuca rubra ssp. rubra

Ficaria verna

Galeopsis tetrahit

Geranium phaeum ssp.phaeum

Heracleum sphondylium ssp.phondylium

Holcus mollis

Hypericum maculatum

Lathyrus pratensis

Leucanthemum ircutianum

Lysimachia nemorum

Lysimachia nummularia

Myosotis sylvatica

Phleum pratense

Pimpinella major var. major

Plantago lanceolata

Poa trivialis

Primula elatior

Prunella vulgaris

Ranunculus acris ssp.acris

Ranunculus repens

Rumex acetosa

Rumex obtusifolius ssp.obtusifolius

Silene dioica

Taraxacum officinale agg.

Trifolium pratense ssp.pratense

Trifolium repens

Trisetum flavescens

Veronica arvensis

Veronica chamaedrys ssp.chamaedrys

Veronica serpyllifolia ssp.serpyllifolia

Vicia cracca

Vicia sepium

\section{\begin{tabular}{|l|l|l|}
2001 & 2005 & 2009 \\
\hline
\end{tabular}}

\begin{tabular}{|r|r|r|}
\hline+ & + & \\
$2 a$ & 1 & $1 a$ \\
\hline $1 a$ & + & +
\end{tabular}
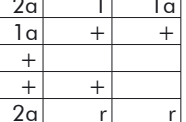

\begin{tabular}{r|r|r}
$2 a$ & $r$ & $r$ \\
\hline $1 b$ & 1 & $1 a$ \\
\hline
\end{tabular}
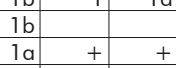

$+\quad+\quad$ Euphrasia officinalis ssp.rostkoviana

\begin{tabular}{c|l|l|l} 
& Festuca pratensis \\
\cline { 1 - 2 } & Festuca rubra ssp. rubra \\
\hline
\end{tabular}
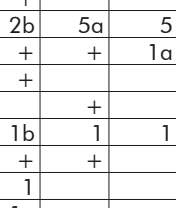

\begin{tabular}{r|r|r}
$1 \mathrm{a}$ & & \\
+ & $2 \mathrm{~b}$ & $3 \mathrm{a}$ \\
\hline
\end{tabular}
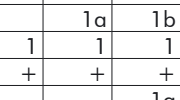

\begin{tabular}{rrr} 
& & $1 a$ \\
\hline$a$ & +
\end{tabular}
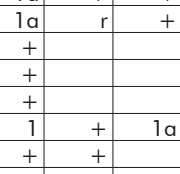

Pimpinella major var. major

2a + + Pimpinella saxifraga ssp.saxifraga

Plantago lanceolata

Platanthera bifolia

Polygala vulgaris ssp.vulgaris

Potentilla erecta

Prunella vulgaris

Prunus spinosa

Pteridium aquilinum

Ranunculus acris ssp.acris

Ranunculus nemorosus

Rumex acetosa

Stellaria graminea

Thymus pulegioides ssp.pulegioides

Tragopogon orientalis

Trifolium aureum

Trifolium medium

Trifolium pratense ssp.pratense

Trifolium repens

Trisetum flavescens

Valeriana officinalis

Veronica chamaedrys ssp.chamaedrys

Veronica officinalis

Viola hirta

Viola riviniana \begin{tabular}{|r|r|r|}
\hline 2001 & 2005 & 2009 \\
\hline+ & + &
\end{tabular}

\begin{tabular}{|r|r|r|}
\hline+ & + & + \\
\hline $1 \mathrm{a}$ & $2 \mathrm{a}$ & 1 \\
\hline & + & + \\
\hline 2 & 1 & $1 \mathrm{~b}$ \\
\hline
\end{tabular}

\begin{tabular}{rr|r|}
+ & + & + \\
\hline $1 a$ & + & +
\end{tabular}

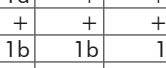

\begin{tabular}{rr|r|}
+ & $1 a$ & $1 a$ \\
\hline 1 & 2 & 2 \\
\hline
\end{tabular}

\begin{tabular}{r|r|r|}
1 & 2 & 2 \\
$2 a$ & $2 b$ & $2 b$ \\
\hline
\end{tabular}

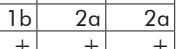

\begin{tabular}{|r|r|r|}
+ & + & + \\
\hline $1 a$ & 1 & $1 a$ \\
\hline
\end{tabular}

\begin{tabular}{r|r|r|}
$1 \mathrm{l}$ & 1 & $1 \mathrm{a}$ \\
\hline $1 \mathrm{~b}$ & 1 & 1 \\
\hline
\end{tabular}

\begin{tabular}{r|r|r|}
$1 b$ & 2 & 1 \\
\hline $1 a$ & $1 a$ & $1 a$ \\
\hline
\end{tabular}

\begin{tabular}{rr|r|}
$1 \mathrm{~b}$ & 1 & $1 \mathrm{a}$ \\
\hline+ & + & +
\end{tabular}

\begin{tabular}{|r|r|r|}
+ & + & + \\
+ & + & + \\
\hline
\end{tabular}

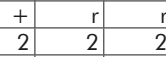

\begin{tabular}{l|r|r}
+ & + & + \\
+ & + & \\
\hline
\end{tabular}

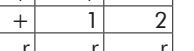

\begin{tabular}{r|r|r|}
$r$ & $r$ & $r$ \\
\hline & & + \\
\hline
\end{tabular}

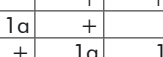

\begin{tabular}{rr|r|}
+ & $1 \mathrm{a}$ & 1 \\
$1 \mathrm{a}$ & + & + \\
\hline
\end{tabular}

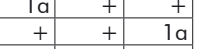

\begin{tabular}{|r|r|r|}
+ & + & + \\
\hline $2 b$ & $2 b$ & $2 b$ \\
\hline & + & $1 a$
\end{tabular}

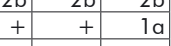

\begin{tabular}{rr|r} 
& & $r$ \\
+ & + & + \\
+ & $1 a$ & $1 a$
\end{tabular}

\begin{tabular}{rr|r|}
+ & $1 a$ & \\
+ & + &
\end{tabular}

\begin{tabular}{rr|r|}
\hline la & + \\
\hline & $1 a$ \\
\hline
\end{tabular}

$\begin{array}{lll}1 b & 1 a & 1 a\end{array}$

\begin{tabular}{rr|r|}
$2 a$ & $2 a$ & + \\
+ & $1 a$ & $1 a$ \\
\hline
\end{tabular}

\begin{tabular}{rrrr}
$1 a$ & + & $r$ \\
\hline & + & +
\end{tabular}

$1 \mathrm{~b} \quad 1 \mathrm{a}$

\begin{tabular}{rr|r|}
$2 a$ & $1 a$ & + \\
\hline+ & &
\end{tabular}

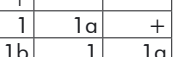

$1+$
+
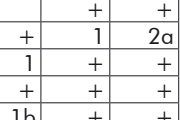

\begin{tabular}{r|r|r|}
\hline $1 \mathrm{~b}$ & + & + \\
\hline 1 & + & + \\
\hline
\end{tabular}

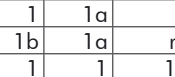

\begin{tabular}{r|r|r|}
+ & + & + \\
\hline 1 & 1 & 2 \\
\hline $2 a$ & $2 a$ & 2 \\
\hline
\end{tabular}
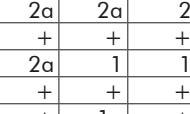

\begin{tabular}{r|r|r|}
\hline+ & $1 \mathrm{a}$ & + \\
\hline $1 \mathrm{~b}$ & $1 \mathrm{~b}$ & 1 \\
\hline
\end{tabular}

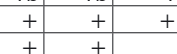

\begin{tabular}{|r|r|r|}
\hline $1 b$ & $1 b$ & 2 \\
\hline
\end{tabular}
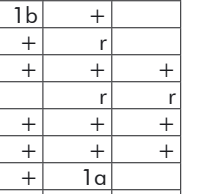

1a
Appendix 4-Changes in the vascular plant species composition on the grazed slope site during the period 2001-2009.

\begin{tabular}{|l|l|l|l|}
\hline Species & 2001 & 2005 & 2009 \\
\hline
\end{tabular}

Acer pseudoplatanus

Achillea millefolium agg.

Agrimonia eupatoria

Agrostis capillaris

Ajuga reptans

Alchemilla glabra

Alchemilla monticola

Anemone nemorosa

Anthoxanthum odoratum

Astrantia major var. major

Betonica officinalis

Briza media

Campanula scheuchzeri

Carex caryophyllea

Carex flacca

Carex hirta

Carex pallescens

Carex panicea

Carex sylvatica

Carex umbrosa

Carlina acaulis ssp.acaulis

Centaurea jacea $\times$ C. macroptilon

Cerastium holosteoides

Chaerophyllum aureum

Clinopodium vulgare

Colchicum autumnale

Crepis biennis

Cruciata laevipes

Dactylis glomerata

Danthonia decumbens ssp. decumbens

Deschampsia cespitosa

Euphrasia officinalis ssp.rostkoviana

Festuca pratensis

Festuca rubra ssp.rubra

Fragaria moschata

Fraxinus excelsior

Galium album

Hieracium lactucella

Hypericum maculatum

Hypericum perforatum

Knautia arvensis ssp.arvensis

Lathyrus pratensis

Leontodon hispidus ssp.hispidus

Leucanthemum ircutianum

Lotus corniculatus

Luzula multiflora

Lysimachia nemorum

Malus sylvestris

Molinia caerulea

Nardus stricta

Orchis mascula

Pimpinella major var. major

Pimpinella saxifraga ssp.saxifraga

Plantago lanceolata

Plantago media

Platanthera bifolia

Polygala vulgaris ssp.vulgaris

\begin{tabular}{|l|} 
Potentilla erecta \\
\hline Prunella vulgaris \\
\hline
\end{tabular}

Prunus spinosa

Pteridium aquilinum

Ranunculus acris ssp.acris

Ranunculus nemorosus

Rumex acetosa

Stellaria graminea

Taraxacum officinale agg.

Thymus pulegioides ssp.pulegioides

Tragopogon orientalis

Trifolium aureum

Trifolium medium

Trifolium montanum

Trifolium pratense ssp.pratense

Trifolium repens

Trisetum flavescens

Veronica chamaedrys ssp.chamaedrys

Veronica officinalis

Vicia sepium

Viola hirta

Viola riviniana

\begin{tabular}{|r|r|r|}
\hline 2001 & 2005 & 2009 \\
\hline$r$ & $r$ & + \\
\hline 1 & $2 a$ & $1 b$ \\
\hline & & \\
\hline
\end{tabular}

\begin{tabular}{|r|r|r|}
\hline $1 b$ & $1 b$ & $1 b$ \\
\hline
\end{tabular}

\begin{tabular}{|r|r|r|}
\hline+ & $1 \mathrm{a}$ & + \\
\hline+ & $1 \mathrm{a}$ & + \\
\hline $1 \mathrm{~b}$ & $1 \mathrm{~b}$ & 1 \\
\hline
\end{tabular}

\begin{tabular}{|r|r|r|}
+ & + & + \\
\hline 2 & 2 & $2 a$ \\
\hline 1 & 1 & 1 \\
\hline
\end{tabular}

\begin{tabular}{|l|l|l|}
$2 a$ & 2 & 2 \\
\hline
\end{tabular}

\begin{tabular}{rr|r|}
$2 a$ & 2 & 2 \\
$2 a$ & $1 b$ & $2 a$ \\
+ & + & +
\end{tabular}

\begin{tabular}{|r|r|r|}
+ & + & + \\
\hline $1 b$ & $1 b$ & $2 a$ \\
\hline
\end{tabular}

\begin{tabular}{r|r|r|}
$2 a$ & 1 & $1 a$ \\
\hline $1 a$ & + & $r$
\end{tabular}

\begin{tabular}{|r|r|r|}
\hline 1 & $1 a$ & $1 a$ \\
\hline 1 & $1 a$ & + \\
\hline $1 a$ & $1 a$ & $1 a$ \\
\hline $1 b$ & 1 & $1 a$ \\
\hline 1 & + & +
\end{tabular}

\begin{tabular}{|r|r|r|}
\hline 1 & + & + \\
\hline+ & $\mathrm{r}$ & \\
2 & 2 & 2 \\
\hline $1 \mathrm{a}$ & + & + \\
\hline+ & + & + \\
\hline
\end{tabular}

\begin{tabular}{|r|r|r}
\hline $1 a$ & + & + \\
+ & + & + \\
\hline $1 a$ & $1 a$ & $1 a$ \\
+ & $r$ & +
\end{tabular}

\begin{tabular}{|rr|r|r} 
& + & $r$ & \\
& + & 2 & 2 \\
& $1 a$ & 1 & \\
\hline & $2 a$ & 1 & \\
\hline & + & + & $1 a$ \\
\hline
\end{tabular}

\begin{tabular}{|r|r|r|}
+ & + & $1 a$ \\
\hline 1 & + & + \\
\hline $1 b$ & $2 a$ & 1 \\
\hline
\end{tabular}

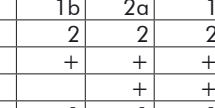

\begin{tabular}{|r|r|r|r|}
\hline 1 & 1 & 1 \\
\hline $1 a$ & $1 a$ & 10 \\
\hline & + & \\
\hline
\end{tabular}

\begin{tabular}{|l}
\hline \\
\hline \\
\hline
\end{tabular}

\begin{tabular}{|r|r|r|}
\hline 2 & 1 & \\
+ & $1 a$ & \\
\hline $1 a$ & + & \\
\hline 1 & 1 & 10 \\
\hline
\end{tabular}

\begin{tabular}{|r|r|r|}
\hline 1 & + & \\
\hline $2 a$ & 2 & 2 \\
\hline $1 b$ & 1 & $1 a$ \\
\hline 1 & 1 & 1 \\
\hline & 1 &
\end{tabular}

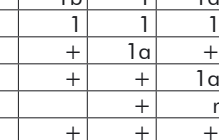

\begin{tabular}{|r|r|r|}
\hline+ & + & + \\
\hline 1 & $1 a$ & $1 a$ \\
\hline
\end{tabular}

\begin{tabular}{|r|r|r|}
\hline $2 a$ & $r$ & $r$ \\
\hline+ & + & $r$ \\
\hline 2 & $2 a$ & 2 \\
\hline
\end{tabular}

\begin{tabular}{rr|r|r}
+ & + & $r$ \\
2 & $2 a$ & 2 \\
$1 a$ & + & + \\
\hline & + & \\
$2 a$ & + & +
\end{tabular}

\begin{tabular}{|r|r|r|}
\hline $2 a$ & + & + \\
\hline $1 b$ & 1 & 1 \\
\hline 1 & $1 b$ & 2 \\
\hline 1 & $1 a$ & $1 a$ \\
\hline
\end{tabular}

\begin{tabular}{|r|r|r|}
1 & $1 b$ & 2 \\
\hline 1 & $1 a$ & $1 a$ \\
\hline $1 b$ & + & + \\
1 & $1 a$ & + \\
\hline
\end{tabular}

\begin{tabular}{r|r|r}
1 & $1 \mathrm{a}$ & + \\
\hline 2 & $1 \mathrm{~b}$ & 1 \\
\hline $\mathrm{r}$ & + & + \\
\hline
\end{tabular}

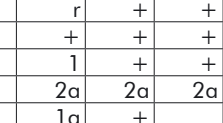

\begin{tabular}{|r|r|r|}
\hline $2 a$ & $2 a$ & $2 a$ \\
\hline $1 a$ & + & \\
\hline & $1 a$ & + \\
\hline
\end{tabular}

\begin{tabular}{|r|r|r|}
\hline $1 b$ & 1 & $1 a$ \\
\hline+ & $r$ & \\
\hline+ & 1 & $1 a$ \\
\hline
\end{tabular}

\begin{tabular}{rr|r|}
+ & 1 & 1 \\
+ & + & \\
+ & $1 a$ & $1 a$ \\
$r$ & 1 & 1
\end{tabular}

\begin{tabular}{r|r|r|}
+ & $\mathrm{r}$ & $\mathrm{a}$ \\
\hline & 1 & 1 \\
\hline+ & $\mathrm{r}$ & \\
\hline+ & + & $\mathrm{r}$ \\
\hline
\end{tabular} 